\title{
The Origin of Green Icebergs in Antarctica
}

\author{
J. KIPFSTUHL, G. DIECKMANN, AND H. OERTER
}

Alfred-Wegener-Institut für Polar- und Meeresforschung, Bremerhaven, Germany

\section{H. HELLMER}

Lamont Doherty Geological Observatory, Palisades, New York

\author{
W. GRAF
}

GSF- Forschungszentrum für Umwell und Gesundheit GmbH, Neuherberg, Germany

\begin{abstract}
A comparison of samples from a translucent green iceberg with a core from the Ronne Ice Shelf revealed an excellent agreement in isotopic composition, crystal structure, and incorporated sediment particles. Marine shelf ice which constitutes the basal portion of some ice shelves is considered to be the source of green icebergs. It most likely results from "ice pump" processes which produce large amounts of ice platelets in the water column beneath ice shelves. These subsequently accumulate and become compacted into bubble-free, desalinated ice. Iceberg and drift-buoy trajectories indicate that green icebergs observed in the Weddell Sea originate from the Amery Ice Shelf rather than from the Ronne Ice Shelf, although this ice shelf is also a potential source.
\end{abstract}

\section{INTRODUCTION}

Observations of colored icebergs in polar regions are well documented [Moulton and Cameron, 1976; Amos, 1978; Jacobs et al., 1979; Dieckmann et al., 1987; Betts, 1988; Lee, 1990]. The dark and opaque coloring of icebergs could usually be attributed to morainal inclusions. However, the origin of green icebergs could only be speculated on. The green appearance of translucent icebergs (Plate 1) was first thought to be due to pigmented inclusions [Moulton and Cameron, 1976; Amos, 1978; Jacobs et al., 1979]. Dieckmann et al. [1987] surmised that layers of fine sediment most likely derived from the seafloor altered the optical characteristics or radiative transfer of an iceberg they studied and gave it a green appearance. Theory and spectral reflectance measurements of green iceberg photographs, however, support the idea that the green color of some icebergs and the one examined by Dieckmann et al. [1987] results from the combination of the ice's intrinsic optical properties and its illumination by reddened sunlight rather than from incorporated particles [Lee, 1990]. While the latter explanation for the green coloration in icebergs is plausible yet controversial, the question of the origin of such icebergs and the terrigenous inclusions has remained unanswered. We advance a mechanism which leads to the formation of translucent green icebergs and support our ideas with new evidence obtained from direct observations of an iceberg sample and an ice core from the central part of the Ronne Ice Shelf. On the basis of studies of iceberg trajectories around Antarctica, we discuss the probable source of the green icebergs observed in the Weddell Sea.

\section{SAMPLING PROCEDURE AND ANALYSES}

A comparison of samples from a green iceberg, a core through the Filchner Ice Shelf as well as ice platelets, is based

Copyright 1992 by the American Geophysical Union.

Paper number 92JC01754.

$0148-0227 / 92 / 92$ JC-01754\$05.00 on the following analyses: A 20-kg chunk of ice was removed from a translucent green iceberg found drifting in the Weddell Sea near Kapp Norvegia at $72^{\circ} 14^{\prime} \mathrm{S}, 18^{\circ} 17^{\prime} \mathrm{W}$ (Figure 3) (see Dieckmann et al. (1987) for details). More recently, an ice core (B13) with a diameter of $72 \mathrm{~mm}$ and total length of $215 \mathrm{~m}$ was drilled in the Ronne Ice Shelf at $76^{\circ} 59^{\prime} \mathrm{S}, 52^{\circ} 16^{\prime} \mathrm{W}$ (Figure 3) in order to reach the layer of marine shelf ice below the radio echo sounding (RES) horizon at about $150 \mathrm{~m}$ depth [Oerter et al., 1992]. Also, loose ice platelets were collected from below the 2-m-thick fast ice in Atka Bay [Kipfstuhl, 1991] and at a depth of approximately $250 \mathrm{~m}$ in Gould Bay in front of the Filchner Ice Shelf [Dieckmann et al., 1986].

The iceberg sample, the core and ice platelets were frozen at $-30^{\circ} \mathrm{C}$ and returned to the home laboratory in Bremerhaven, Germany. Subsequent processing of the samples was done in a $-30^{\circ} \mathrm{C}$ laboratory. Horizontal and vertical thin sections were prepared from the core using a band saw and microtome. Thin sections from the green iceberg sample, however, were cut perpendicular and parallel to the particle layers. Sections were frozen onto glass plates and subsequently photographed under crossed polarizers as well as under normal light.

Microscopic analyses of dried samples of the green iceberg and core were carried out as described by Dieckmann et al. [1987]. Subsamples of the ice platelets, the green iceberg, and the core were melted to measure electrolytic conductivity and stable isotope concentrations. Hydrogen and oxygen isotope concentrations of the melted ice samples were determined by standard techniques at the Institut für Umweltphysik, Heidelberg, Germany, and at the GSF-Forschungszentrum in Munich. $\mathrm{HDO}$ and $\mathrm{H}_{2}{ }^{18} \mathrm{O}$ concentrations will hereinafter be denoted in $\delta$ units versus Vienna Standard Mean Ocean Water (VSMOW). Accuracy of the $\delta \mathrm{D}$ measurements is $\pm 1 \%$ and of $\delta^{18} \mathrm{O}$ measurements $\pm 0.1 \%$.

\section{Results}

As described by Dieckmann et al. [1987], the chunk of ice chipped from the green iceberg had a clear white color after separation and contained distinct layers of mineral and bio- 


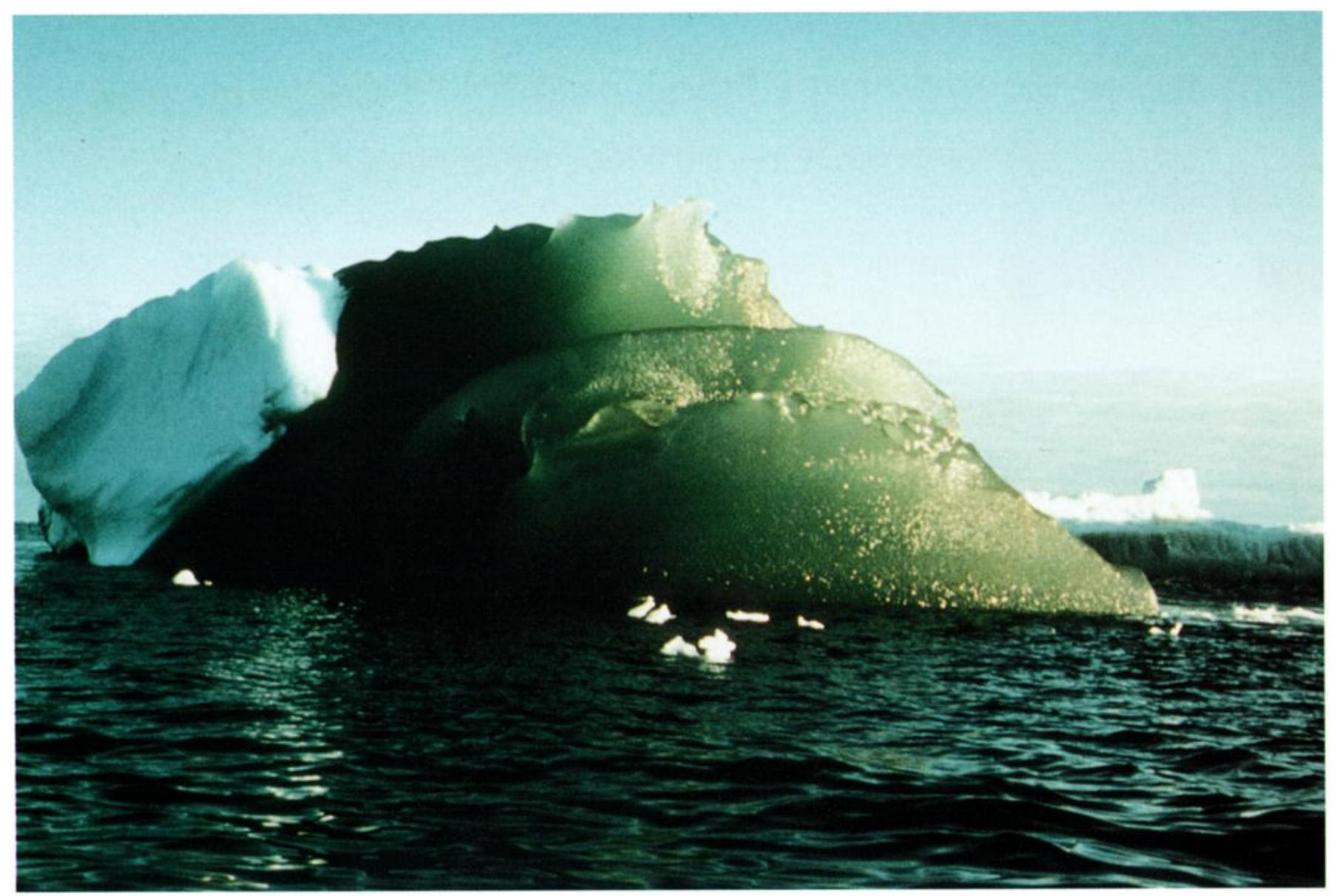

Plate 1. Photograph of green iceberg discussed by Dieckmann et al. [1987] and Lee [1990], showing remnants of meteoric ice.

genic debris in the form of individual particles or lumps (Figure 1a). No organisms or particles which could have been directly responsible for the green colouration of the iceberg were found. Crystal analysis under polarized light revealed small elongated grains in more or less parallel layers interspersed with small round grains (Figure 1c).

The Ronne Ice Shelf at the site of the coring was $233 \mathrm{~m}$ thick [Oerter et al., 1992], and the length of the core taken there was $215 \mathrm{~m}$. The transition from meteoric ice to marine shelf ice was found at a depth of $152.8 \mathrm{~m}$, where the bubbly ice of meteoric origin changed abruptly to clear bubble-free ice containing entrained particles very similar to those in the green iceberg (Figure $1 b$ ). The inclusions also occurred in layers, clearly visible in the vertical section of the core (Figure 1e). Spacing of the layers was only a few millimeters near the top but increased to several centimeters toward the bottom of the core. Preliminary microscopic analyses of the inclusions in the core yielded mainly clastic particles, diatom frustules, and remnants of radiolarians similar to those in the green iceberg [Dieckmann et al., 1987]. Also the crystal structure in the topmost layers of the marine shelf ice is almost identical to that observed in the green iceberg (Figure 1d).

Table 1 shows a summary of stable isotopes ${ }^{18} \mathrm{O}$ and $\mathrm{D}$ as well as electrolytical conductivities of the green iceberg, the core and ice platelets. There is good agreement between the $\delta$ values of the green iceberg, the marine shelf ice of the core and the ice platelets. Despite the extremely low salinity of the marine shelf ice, the isotope analyses clearly reveals its seawater origin. The iceberg and the core had electrolytical conductivities between 30 and $200 \mu \mathrm{S} / \mathrm{cm}$, which correspond to salinities below $0.1 \%$. They lie above those of meteoric ice but far below typical sea ice salinities of 3-5\%.

TABLE 1. Stable Isotope Content and Electrolytical Conductivity of a Green Iceberg, an Ice Core Drilled at the Ronne Ice Shelf, and Ice Platelets from Gould Bay (Filchner Ice Shelf) and Atka Bay (Ekström Ice Shelf)

\begin{tabular}{|c|c|c|c|c|}
\hline \multirow{3}{*}{$\begin{array}{l}\text { Parameter } \\
\delta^{18} 0, \% 0\end{array}$} & \multirow[b]{2}{*}{ Green Iceberg } & \multicolumn{2}{|c|}{ Ice Core } & \multirow[b]{2}{*}{ Ice Platelets } \\
\hline & & Marine Shelf Ice & Meteoric Ice & \\
\hline & +1.6 to +2.5 & +1.7 to +2.6 & -25 to -38 & +1.6 to +2.2 \\
\hline $8 \mathrm{D}, \%_{0}$ & +13 to +18 & +14 to +18 & -200 to -300 & +14 to +20 \\
\hline$\sigma, \mu S / \mathrm{cm}$ & 45 to 115 & 30 to 200 & 2 to 20 & ---- \\
\hline
\end{tabular}

Values represent the range determined for minimum of five samples, $\delta$ values as deviation from VSMOW. 


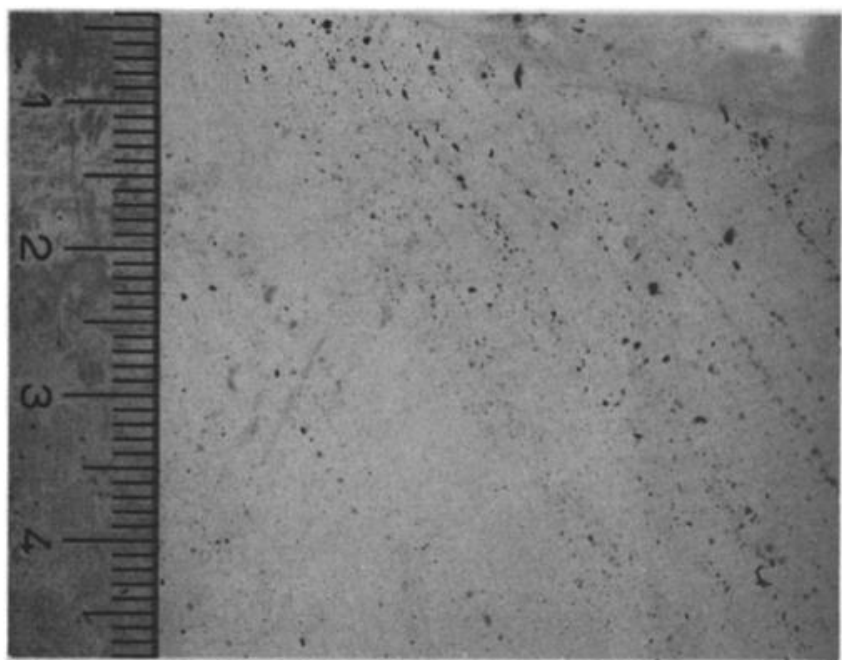

A

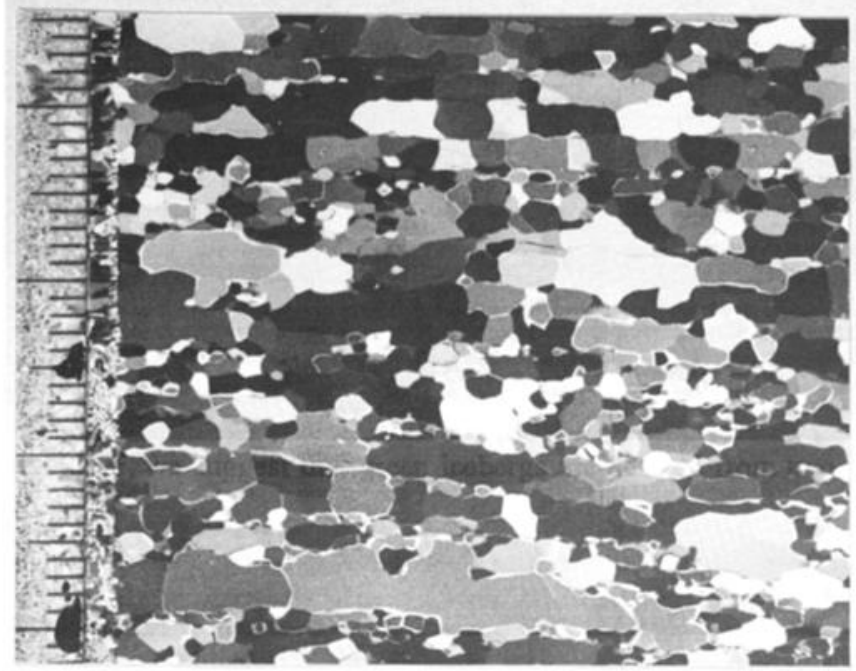

C

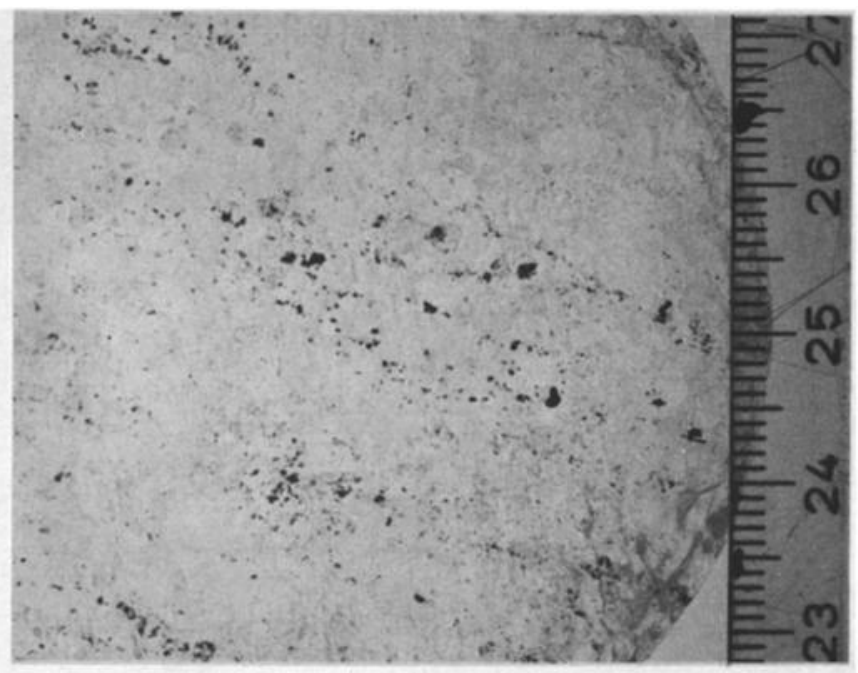

B

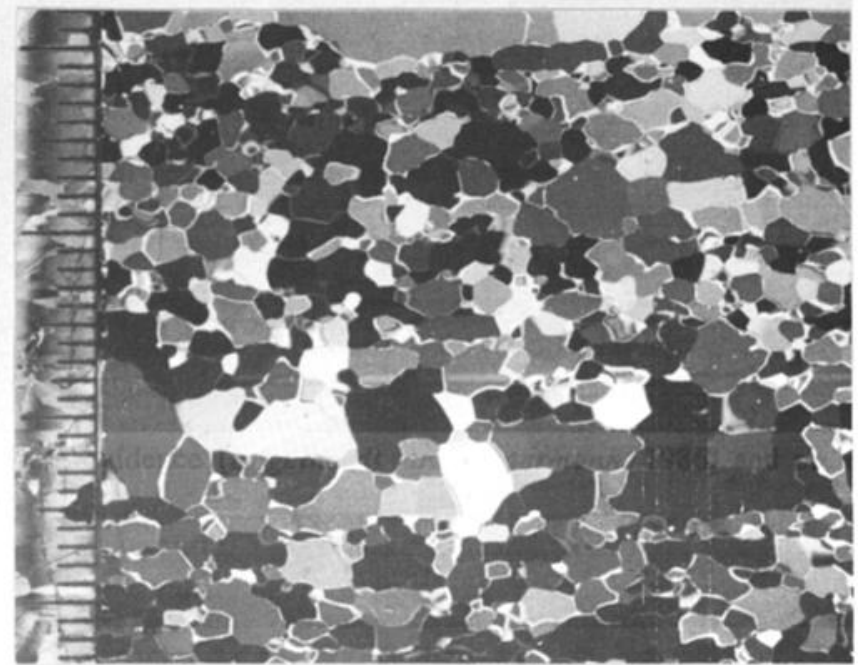

D

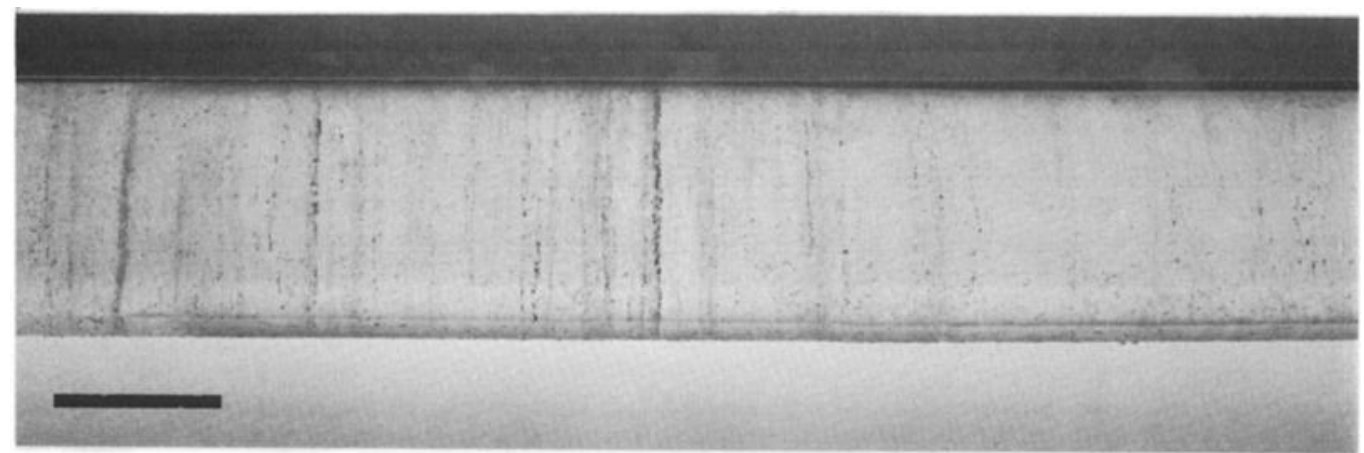

$\mathbf{E}$

Fig. 1. Photographs showing layering and distribution of incorporated sediment particles and crystal structure: (a) Thin section from the green iceberg, (b) Horizontal thin section of the ice core (depth, $153.3 \mathrm{~m}$ ), (c) Thin section from the green iceberg between crossed polarizers. The section is cut perpendicular to the parallel particle layers, $(d)$ Vertical thin section of marine shelf ice between crossed polarizers from the Ronne ice core at a depth of $153.7 \mathrm{~m}$, (e) Segment of an ice core
(depth, 153-154 m) drilled from the Ronne Ice Shelf. Bar $=5 \mathrm{~cm}$.

\section{Discussion}

Because of the good correspondance between ice properties of the green iceberg and the marine shelf ice under the Ronne Ice Shelf, we suggest that green icebergs are derived from two- layered ice shelves with a basal layer of marine shelf ice. Figure 2 is a conceptual model of the processes leading to the formation of marine shelf ice and green icebergs based on bore hole evidence [Engelhardt and Determann, 1986] and on a 


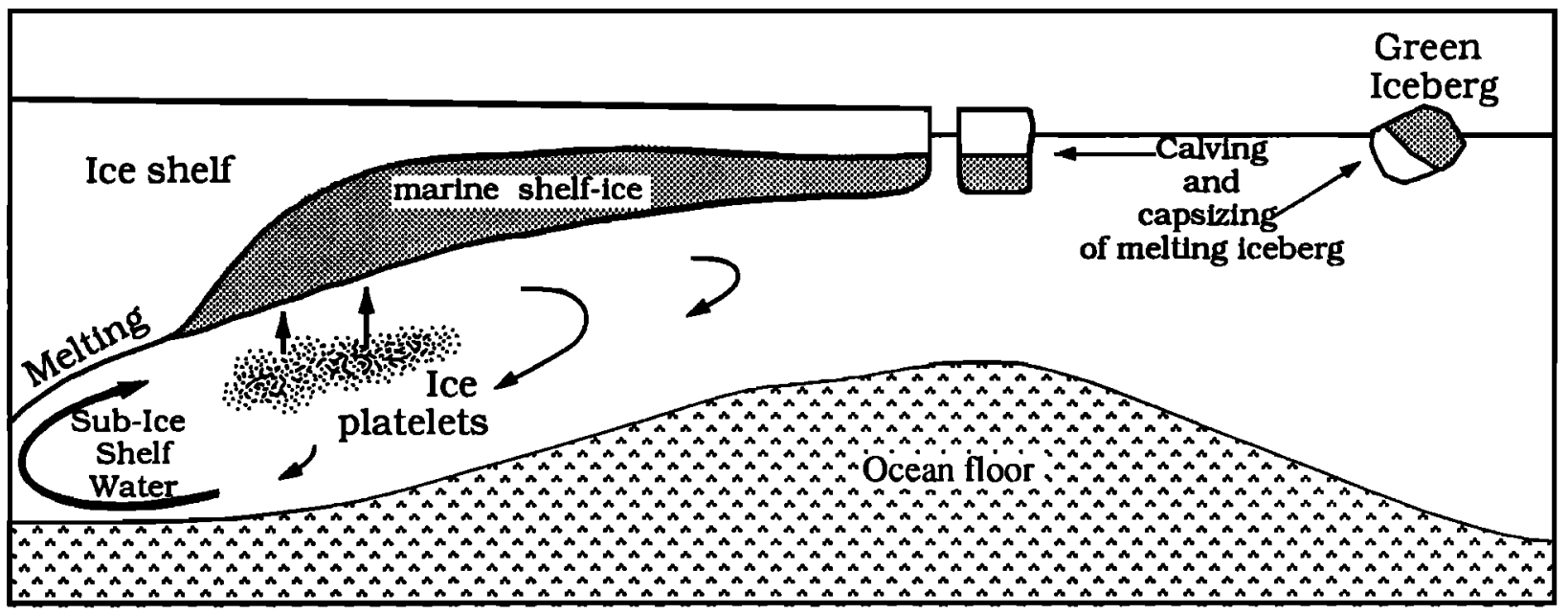

Fig. 2. Conceptual model of processes leading to the formation of green icebergs: Thermohaline convection ("ice pump") which is driven by the change of freezing point with pressure causes melting near the grounding line and leads to the formation of ice crystals in ascending water when the in situ freezing point is reached. Icebergs calving from such twolayered ice shelves are observed as green icebergs once they have capsized.

model of ice platelet formation [Kipfstuhl, 1991]. The underlying mechanism is the "ice pump" described by Lewis and Perkin [1986] which melts ice near the grounding line and produces free underwater ice crystals and platelets within the water column below an ice shelf. The ice crystals, being buoyant, rise and accumulate under the ice shelf, where they form layers of slush some tens of meters thick. The transition process, from an unconsolidated aggregation of loose ice platelets under an ice shelf to solid bubble-free marine shelf ice, is not clear but is likely to be the result of progressive mechanical compaction of the ice crystals at temperatures close to the melting/freezing point.

We do not think that direct basal freezing could lead to marine shelf ice of several hundred meters' thickness on the following grounds: Mass balance calculations indicate basal accumulation rates under the Amery and Ronne ice shelves of up to 1 and $2 \mathrm{~m}$ of solid ice per year [Budd et al., 1982; Determann, 1991]. Yet the freezing of seawater at the base of ice shelves, due to thermal conduction through the ice, is limited to a few centimeters per year [Robin, 1979; Zotikov et al., 1980] and can therefore not account for the layers of marine shelf ice of up to $300 \mathrm{~m}$ thick. Nor would this process contribute much to the freezing and consolidation of an ice platelet layer several tens of meters thick [Engelhardt and Determann, 1986].

We assume that water circulation beneath the ice shelf is driven by the change of freezing point with pressure. Because the "ice pump" is self-starting and functions in a closed system as long as ice thickness gradients exist, melting at the grounding line does not depend on heat input from the open ocean. Thus near the grounding line, where an ice shelf is thickest, the potential to melt ice can be expected to be highest because the freezing point is also depressed most. This is indicated by recent work done on the Filchner-Ronne Ice Shelf and by numerical modeling of the thermohaline circulation beneath an ice shelf [Hellmer and Olbers, 1989; Jenkins and Doake, 1991]. Jenkins and Doake [1991] report basal melting rates of up to $5 \mathrm{~m} / \mathrm{yr}$ near the grounding line at the Rutford Ice Stream while Determann et al. [1990] estimated a rate of only $1.5 \mathrm{~m} / \mathrm{yr}$ close to the ice front. This does not appear to be a specific feature at the Ronne Ice Shelf. Ablation rates of up to $2 \mathrm{~m}$ were determined to occur at the grounding line of the Brunt and Ekström ice shelves [Thomas, 1973; Kipfstuhl, 1991].

The manner in which layers of sediment particles are incorporated into the marine shelf ice is also not yet understood but possibly takes place in a way suggested by Dieckmann et al. [1986], where particles may be "scavenged" by moving clouds of ice platelets on their upward path through the water column. Similar mechanisms are described for sea ice [Garrison et al., 1983; Kempema et al., 1989]. Alternatively or additionally, suspended material may initiate the nucleation of the ice crystals within the water column.

Although bubble-free marine shelf ice originates from seawater, it exhibits properties distinctly different from normal sea ice which forms at the sea surface and is described in detail by Weeks and Ackley [1982]. From surface velocities of the Ronne Ice Shelf we estimate the age of marine shelf ice to be $\geq 500$ years. This is comparable to old sea ice under the Ross Ice Shelf (J-9) and from the Ward Hunt Ice Shelf in the Canadian Arctic which are 400 to 600 years old [Zotikov et al., 1980; Jeffries et al., 1988]. Despite its age, however, this old sea ice still has a salinity between 2 and $4 \%$, which is much higher than that of marine shelf ice and more typical of multiyear sea ice in the Arctic or Antarctic. Furthermore, the old sea ice under the Ross Ice Shelf exhibits other typical sea ice properties such as columnar crystal structure, cellular substructure, and high porosity [Zotikov et al., 1980]. Thus very old sea ice is not likely to be a source of green icebcrgs, although particles of uncertain origin were also found under the Ross Ice Shelf at J-9 [Zotikov et al., 1980]. Souchez et al. [1991] also observed marine shelf ice of different textures and salinities under Hell's Gate Ice Shelf in the Ross Sea, but do not report on any sediment inclusions.

\section{SOURCE OF GREEN ICEBERGS}

Among the large ice shelves underneath which extensive areas of basal layers of marine shelf ice exist are the Ronne and the Amery ice shelves [Budd et al., 1982; Robin et al., 1983; Thyssen, 1988]. At the Ronne Ice Shelf, however, the marine shelf ice layer melts away 30 to $50 \mathrm{~km}$ before it reaches the ice 


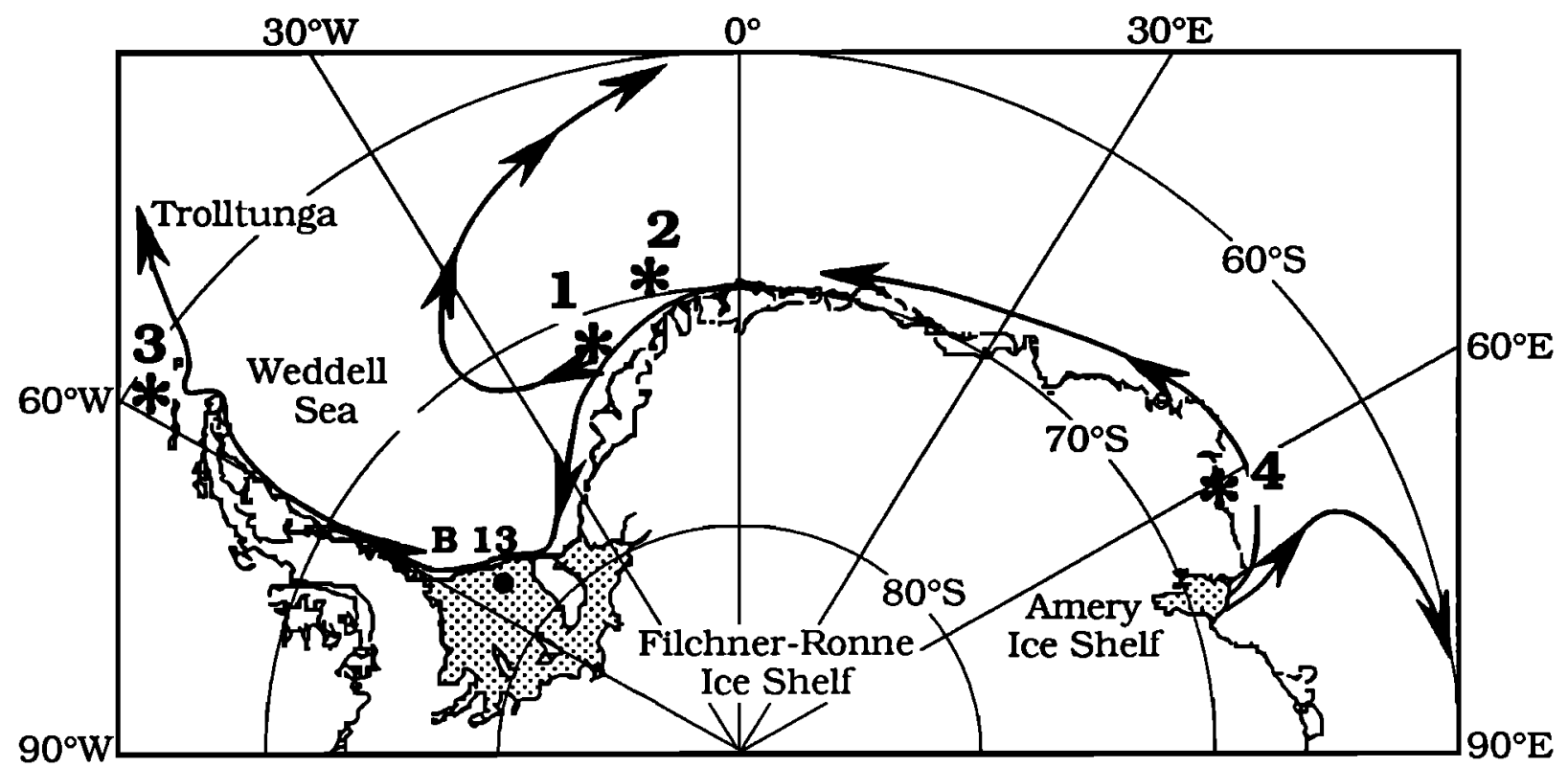

Fig. 3. Map showing position where four green icebergs were observed: (1) Dieckmann et al. [1987], (2) Amos [1978], (3) Moulton and Cameron [1976], and (4) Belts [1988]. Generalized trajectories of icebergs and drift buoys, based on tracking observations by Vinje [1981] and Kottmeier and Hartwig [1990] are also shown. Track of the iformer glacier tongue Trolltunga, after Swithinbank et al. [1977]. The solid dot shows the position of core B13 on the Filchner-Ronne Ice Shelf.

front [Robin et al., 1983; Thyssen, 1988]. Although most green icebergs have been observed in the Weddell Sea sector (Figure 3) and there is excellent agreement in the properties of one of these with marine shelf ice from the Ronne Ice Shelf, translucent green icebergs are more likely to originate from the Amery Ice Shelf. It is only at the Amery Ice Shelf that a basal layer of marine shelf ice about $100 \mathrm{~m}$ thick reaches the ice front [Budd et al., 1982].

We propose that the green iceberg described by Dieckmann et al. [1987] and probably others observed in the Weddell Sea are derived from the Amery Ice Shelf. This is substantiated by tracking observations of icebergs and drift buoys (Figure 3). Close to the Antarctic coast, winds are predominantly easterly and the mean current is to the west. Icebergs calved from Amery Ice Shelf follow the current to the west into the Weddell Sea if they remain in the East Wind Drift. For example, the path of Trolltunga, a glacier tongue which broke off from Fimbulisen [Swithinbank et al., 1977], shows that the green iceberg observed near Livingston Island at $62.6^{\circ} \mathrm{S}$ and $60^{\circ} \mathrm{W}$ [Moulton and Cameron, 1976] could indeed also have originated from the Amery Ice Shelf. A track similar to that of Trolltunga was followed by iceberg 1967B which was first seen at $60^{\circ} \mathrm{E} 4$ years previously [Swithinbank et al., 1977]. On the eastem side of the Antarctic Peninsula the flow of the Weddell Gyre is meridional, and the drift of icebergs from Filchner-Ronne Ice Shelf is northward. Icebergs enter into the westerlies at $60^{\circ} \mathrm{S}$, follow the circumpolar current to the east, and probably melt there.

The existence of marine shelf ice with inclusions, similar to that found under the Ronne Ice Shelf, has not been documented for the Ross Ice Shelf nor for other ice shelves of the Ross Sea sector. Souchez et al. [1991] report on basal freezing under the Hell's Gate Ice Shelf near Terra Nova Bay in the Ross Sea but do not mention particle inclusions. Furthermore, the marine shelf ice observed by them was apparently not entirely bubblefree. This may explain why no green icebergs have been reported from there. Similarly, we know of no reports of green icebergs from the Arctic.

Although the Amery Ice Shelf is the most probable source for green icebergs, the question arises as to why no inclusions are reported from the marine shelf ice part of the Amery Ice Shelf core by Morgan [1972] and the samples which were collected at the Mawson ice edge by Betts [1988].

\section{CONCLUSIONS}

Because of the good correspondance between ice properties of the green iceberg and the marine shelf ice under the Ronne Ice Shelf, we conclude that green icebergs are derived from ice shelves with a basal layer of marine shelf ice and are not distinguishable from other icebergs until they have capsized. The mechanisms responsible for the layering of sediments between modified ice crystals, however, have to be identified more clearly [Oerter et al., 1992]. Green icebergs provide evidence of the effects of oceanographic processes on the dynamics of ice shelves which need to be considered when studying and modelling the mass balance of ice sheets.

Acknowledgments. We wish to thank Petra Mursch, Friedel Hinz, and Marianne Lücker, who prepared thin sections and photographs. Alfred-Wegener-Institut für Polar- und Meeresforschung contribution 567.

\section{REFERENCES}

Amos, A. F., Green iceberg sampled in the Weddell Sea, Antarct. J. U.S., 13, 63-64, 1978.

Betts, M., Why are some icebergs green?, Anare News, Australian Antarctic Division, Kingston, Tasmania, p. 16, Dec. 1988.

Budd, W. F., M. J. Corry, and T. H. Jacka, Results from the Amery Ice Shelf project, Ann. Glaciol., 3, 36-41, 1982.

Determann, J., Numerical modelling of ice shelf dynamics, Antarct. Sci., 3, 187-195, 1991.

Determann, J., K. Großfeld, and B. Ritter, Melting rates at the bottom of Filchner-Ronne Ice Shelf, Antarclica, from short term mass balance studies, Polarforschung, 60, 25-32, 1990. 
Dieckmann, G., G. Rohardt, H. Hellmer, and J. Kipfstuhl, The occurrence of ice platelets at $250 \mathrm{~m}$ depth near the Filchner Ice Shelf and its significance for sea ice biology, Deep Sea Res., 33, 141 $148,1986$.

Dieckmann, G., C. Hemleben, and M. Spindler, Biogenic and mineral inclusions in a green iceberg from the Weddell Sea, Antarctica, Polar Biol., 7, 31-33, 1987.

Engelhardt, H., and J. Determann, Borehole evidence for a thick layer of basal ice in the central Ronne Ice Shelf, Nolure, 327, 318-319, 1986.

Garrison, D. L., S. F. Ackley, and K. R. Buck, A physical mechanism for establishing algal populations in frazil ice, Nalure, 396, 363. $365,1983$.

Hellmer, H. H., and D. J. Olbers, A two-dimensional model for the thermohaline circulation under an ice shelf, Antarct. Sci., 1, 325336, 1989.

Jacobs, S. S., A. L. Gordon, and A. F. Amos, Circulation and melting beneath the Ross Ice Shelf, Science, 203, 469-471, 1979.

Jeffries, M. O., W. M. Sackinger, H. R. Krouse, and H. V. Serson, Water circulation and ice accretion beneath Ward Hunt Ice Shelf (northem Ellesmere Island, Canada), deduced from salinity and isotope analysis of ice cores, Ann. Glaciol., 10, 68-72, 1988.

Jenkins, A., and C. S. M. Doake, Ice-ocean interaction on Ronne Ice Shelf, Antarctica, J. Geophys. Res., 96, 791-813, 1991.

Kempema, E. W., E. Reimnitz, and P. W. Bames, Sea ice sediment entrainment and rafting in the Arctic, J. Sediment. Petrol., 59, 308317, 1989.

Kipfstuhl, J., On the formation of underwater ice and the growth and energy budget of the sea ice in Atka Bay, Antarctica, Rep. Polar Res., 85, 88 pp., Alfred-Wegener-Institut, Bremerhaven, 1991.

Kottmeier, C., and R. Hartwig, Winter observations of the atmosphere over Antarctic sea ice, J. Geophys. Res., 95, 16,551-16,560, 1990.

Lee, R. J., Green icebergs and remote sensing, J. Opt. Soc. Am. A Opt. Image Sci., 7, 1862-1874, 1990.

Lewis, E. L., and R. G. Perkin, R., Ice pumps and their rates, $J$. Geophys. Res., 91, 11,756-11,762, 1986.

Morgan, V. I., Oxygen isotope evidence for bottom freezing on the Amery Ice Shelf, Nalure, 238, 393-394, 1972.

Moulton, K. N., and R. L. Cameron, Bottle-green iceberg near the ' South Shetland Islands, Antarct. J. U.S., 11, 94-95, 1976.
Oerter, H., J. Kipfstuhl, J. Determann, H. Miller, D. Wagenbach, A Minikin, and W. Graf, Ice-core evidence for basal marine shelf ice in the Filchner-Ronne Ice Shelf, Nature, 358, 399-401, 1992.

Robin, G. de Q., Formation, flow and disintegration of ice shelves, J. Glaciol., 24, 259-271, 1979.

Robin, G. de Q., C. S. M. Doake, H. Kohnen, R. D. Crabtree, S. R. Jordan, and D. Möller, Regime of the Filchner-Ronne ice shelves, Antarctica, Nature, 302, 582-586, 1983.

Souchez, R., M. Meneghel, J.-L. Tison, R. Lorrain, D. Ronveaux, C. Baroni, A. Lozej. I. Tabacco, and J. Jouzel, Ice composition evidence of marine ice transfer along the bottom of a small Antarclic ice shelf, Geophys. Res. Lett., 18, 849-852, 1991.

Swithinbank, C., P. McClain, and P. Little, Drift tracks of Antarctic icebergs, Polar Rec., 18, 495-501, 1977.

Thomas, R. H., The dynamics of the Brunt Ice Shelf, Coats Land, Antarctica, Br. Antarct. Surv. Sci. Rep., 79, 45 pp., 1973.

Thyssen, F., Special aspects of the central part of Filchner-Ronne Ice Shelf, Antarctica, Ann. Glaciol., 11, 173-179, 1988.

Vinje, T. E., Some satellite-tracked iceberg drifts in the Antarctic, Ann. Glaciol., 1, 83-87, 1980.

Weeks, W. F., and S. F. Ackley, The growth, structure, and properties of sea ice, CRREL Monogr. 82-1, 130 pp., U.S. Ammy Cold Reg. and Eng. Lab., Hanover, N.H., 1982.

Zotikov, I. A., V. S. Zagorodnov, and J. V. Raikovsky, Core drilling through the Ross Ice Shelf (Antarctica) confirmed basal freezing, Science, 207, 1463-1465, 1980.

J. Kipfstuhl, G. Dieckmann, and H. Oerter, Alfred-Wegener-Institut für Polar- und Meeresforschung, Columbusstrasse, 2850 Bremerhaven, Germany

W. Graf, GSF- Forschungszentrum für Umwelt und Gesundheit GmbH, 8042 Neuherberg, Germany

H. Hellmer, Lamont-Doherty Geological Observatory, Palisades, NY 10964.

(Received November, 1991;

revised July 9, 1992;

accepted July 17, 1992.) 